\title{
REVIEWS \\ ARVOSTELUT
}

\author{
CHRISTIAN BANK PEDERSEN
}

\section{A Decadent Ophelia}

Viola Parente-Čapková (20I 4): Decadent New Woman (Un)Bound: Mimetic Strategies in L. Onerva's Mirdja, Turku, University of Turku, 269 p.

According to a note in Viola Parente-Čapková's Decadent New Woman (Un)Bound, L. Onerva - pen name of poet, critic and novelist Hilja Onerva Lehtinen (1882-1972) - belonged to the first generation of Finnish women able to access higher education without a prior special study permit, granting the female student "freedom from her sex", "erivapaus sukupuolesta" (p. III). So, if you will, L. Onerva and her rather few women colleagues entering university at the turn of the twentieth century constituted quite an original phenomenon, liberated from the obligation to be 'freed' from their sex as they were. But if that was really a (new) beginning, how were these women supposed to get started? Until then, not being a man was something you had to be dispensed from. Logically, what followed was thus an odd liberation from a pure negativity. If you need to be freed from your sex to educate yourself - and thereby fulfil what you already are -, then who, or what, are you really? A liberated non-entity. If you do no longer need to be liberated from what you are to become yourself, then what does that make you? Same as above, basically. In any case, you are 'liberated' from what society considers your own deficiency, your own shortfall. You are liberated from being a woman. Obviously, the question of finding a model to follow - and to leave behind, eventually - becomes crucial.

In her study of the early work of L. Onerva, a modernist writer having long stood in the shadow of her male contemporaries, ParenteČapková emphasises the importance of the mimetic strategies by means of which the author creates, or constructs, female subjectivity in the context of fin-de-siècle decadence: which version of the New Woman comes to light in L. Onerva's writings from the beginning of the twentieth century, first and foremost her debut novel Mirdja, published in 1908? Originally invented by the Irish writer Sarah Grand 
(I854-1943), the term "New Woman" represents in Parente-Čapková's book "a discursive construction" eminently related to the "concerns of middle class women" (p. 8). Specifically, she uses the term to "point to the various means by which fin-de-siècle thinkers and artists/writers created a conception of female subjectivity that differed from previous conceptions" (p. 8). Guided by Ebba Witt-Brattström, Parente-Čapková refines this definition by characterizing the New Woman as a "figure negotiating the divide between nineteenth century discourses on sexuality and the contemporary women's movement(s)" (p. 8). The divide in question seems a difficult one to negotiate.

The conception of mimesis elaborated by Luce Irigaray plays a very important part in the theoretical framework presented by ParenteČapková: Given the absence, pointed out by Irigaray, of "a maternal genealogy in Western thought" (p. I8I), which "image of woman" could possibly be transmitted from mother to daughter? None, really, at least not "a culturally accessible and respected" one (p. 18I; Parente-Čapková refers to the work of Margaret Whitford). This is where the Irigarayan notion of mimesis comes into play: In Western thought, truth is One and truth is Male, the masculine reproducing its own representational patterns in a trans-historical order that leaves no room for the female. Woman is but the 'other' of the one and eternally undivided 'same', the masculine in the truth of its own reflection. A new mirror is needed.

According to Parente-Čapková, Luce Irigaray conceives mimesis "as a strategy of 'playful repetition', that is, 'playing with mimesis', serves to identify the role of femininity without allowing oneself to be simply reduced to it, requiring distance" (p. 24). Through this distance, irony and parody come forth as useful strategies of defamiliarization vis-à-vis the reflected image that is not one's 'own'. Following the 'Platonic' division at the heart of Irigaray's notion of mimesis - as well as the developments proposed by Naomi Schor and Hillary Robinson - Parente-Čapková considers the "productive" and the "non-productive" mimesis at work in L. Onerva's Mirdja, a novel that, according to the concluding remarks of Decadent New Woman (Un)Bound, must be read as "a picara novel and a decadent picara novel” (p. 223; see also p. 24 and p. 219), subverting, and 'playing with', the traditions of the Bildungs- and Künstlerroman of the nineteenth century.

Productive mimesis is intimately associated with a Nietzschean sphere of aesthetic play, deconstruction and reconstruction, while nonproductive mimesis stays put within the orderly lines of verisimilitude and thereby confirms the hold of the existing male order, and the models for identification it has to 'offer'. With these theoretical tools at her disposal, Parente-Čapková enters the decadent universe of Mirdja to investigate not only how L. Onerva depicted, or created, "woman's (artistic) subjectivity in her early work", but also how various aspects of mimesis related to her conception of "women's emancipation" more generally considered (p. 17).

In her convincingly argued and well-structured study, ParenteČapková therefore analyses closely the existential and artistic wanderings of Mirdja, the main character of L. Onerva's eponymous novel. Firmly 
placing the work in the context of decadence - with its abolition of the distinction between art and life and its primacy given to art in relation to reality -, the author offers a thorough reading of a multifaceted mimesis, reflecting both the representational choices made by L. Onerva in the writing of Mirdja and the mimetic options available to Mirdja as a character representative of a generation of women torn between "outer bindings" and "inner inhibitions" (p. 18). Through main chapters covering mimesis as "identification" - identification mainly with (dilettantish) male role models who offer education by means of seductive artistic games -, and analysing with great care the theme of love and its imitative aspects as well as the (im)possible search for an origin in the figure of the 'Mother', Parente-Čapková presents an interesting perspective on Mirdja as a woman's Künstlerroman relating the story of a heroine who never quite finds an 'art' of her own, be it an art of living, creating, or loving. It should be added that in her very detailed reading of L. Onerva's work Parente-Čapková never lets the socio-historical context out of sight, staying loyal all the way, one could say, to the author's own conviction of the inseparability of aesthetics and politics: from Paul Bourget and Oscar Wilde to the rather conservative Lutheran elements within the Finnish women's movement, a wide variety of formal and thematic aspects of the Nordic and European fin-de-siècle is put into play, shedding new light on the ways in which L. Onerva regarded, and transformed, questions of gender identity, sexual difference and artistic desire, among others.

That being said, the theoretical framework put into place by Parente-Čapková suffers from some minor lapses. From time to time, for instance, the references seem to be rather distanced from the original source. Let's take the example of Nietzsche, whose conception of (self)creation is of utmost importance to L. Onerva and, therefore, to the author of Decadent New Woman (Un)Bound. Discussing Nietzsche's somewhat complex presence in the cultural sphere of the fin-de-siècle, Parente-Čapková states:

\footnotetext{
Women writers' creative appropriation of Nietzsche's ideas (cf. Diethe 1996; Heczková 2003; Parente-Čapková 2004; WittBrattström 2007, etc.), was often, though not necessarily, intertwined with decadence. Nietzsche's uses of "woman" are multiple and contradictory, referring at once to embodied women, female mythic figures and metaphors (cf. e.g. Pulkkinen 2002, 383). Nietzsche's ideas about women, femininity and gender, at once provocative and stimulating (cf. Heczková 2003), are of important intertextual relevance to L. Onerva's Mirdja, as well as Nietzsche's complex stance on decadence. (pp. 16-17)
}

That may very well be a sound consideration of Nietzsche's "uses of 'woman" and of his "ideas about women". The ideas in question were certainly far from simple. But wouldn't it have been appropriate to actually quote some of those ideas here? Which Nietzsche, whose Nietzsche, are we really talking about? The same argument could be made concerning the treatment given to Jacques Lacan a little further on in Parente-Čapková's book, when the French psychoanalyst's conception of the Mirror Stage is being discussed without a single quote from the 
author himself (Pp. 50-5I). From a very different angle, I have difficulty understanding the absence of any mention of the work of Judith Butler in a dissertation that seeks to consider "the instability of the meanings given to gender and sexual identity" (p. 22I).

However, these remarks should not deflect attention from the fact that Parente-Čapková has written a thoughtful interpretation of a work that is still, regrettably, fairly unknown outside of Finland. She writes with comprehensive historical knowledge and theoretical care the abovementioned objections set aside - and positions herself clearly in relation to her feminist predecessors of the eighties and nineties (Päivi Lappalainen, Lea Rojola and Pirjo Lyytikäinen, among others). Most impressively, her dedication to the specificities of L. Onerva's writing never seems to falter. In fact, the attention to detail remains decisive right up until the reading of Mirdja's bitter end, i.e. the heroine's death by drowning in the marshes - as an Ophelia of the bogs - in search for the child she never had. This death scene is, I take it, as far from any ideal as from any ultimately distancing irony. It is, after all, always a question of "real woman", as Parente-Čapková rightly points out at the very beginning of her book.

\section{Author}

Christian Bank Pedersen, Associate professor, Department of Nordic Studies, Research group ERLIS EA 4254, Université de Caen Normandie christian-bank.pedersen[at]unicaen.fr).

JUDITH MEURER-BONGARDT

\section{Bertel Gripenberg - A Modern Writer}

\section{Anna Möller-Sibelius: Roll, retorik och modernitet i Bertel Gripenbergs lyrik. Skrifter utgivna av Svenska litteratursällskapet i Finland 79I, SLS 20I5. 352 s.}

During his lifetime Bertel Gripenberg (I878-1947) was a very popular Finland Swedish author, who was even a strong candidate for the Nobel Price. Today he is often seen as a pioneer representative of the traditionalists, a movement known for its opposition against the new modernist generation with poets like Edith Södergran. Gripenberg is not only presented as being a conservative with respect to form and content in poetry, but as a glorifier of war who publicly displayed a fascist attitude. Revealing some parallels to the Norwegian author Knut 